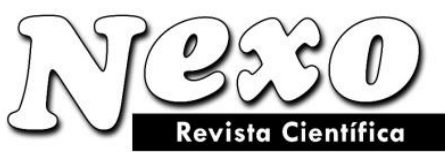

Vol. 34, No. 01, pp. 310-319/Marzo 2021

\title{
Emergence of the open innovation model and factors of transition to it
}

\section{Aparición del modelo de innovación abierta y factores de transición hacia él}

\author{
Natalya Udaltsova \\ Financial University under the Government of the Russian Federation, Moscow, Russia. \\ NLUdaltsova@fa.ru
}

(recibido/received: 19-November-2020; aceptado/accepted: 18-January-2021)

\begin{abstract}
Modern transnational companies are increasingly resorting to the open innovation model. The role of innovation is growing all over the world. The development and implementation of innovations in the current activities of companies characterize the effective competitive development of an organization in the market. This model has a number of advantages: faster development of innovations, the ability to save on $R \& D$ via outsourcing innovations, access to the most modern innovations of other companies, etc. The purpose of this study is to identify the factors that determine the transition of an increasing number of companies in the world to the open innovation model. In this paper, using the analysis of academic literature, various views on this process have been considered. The work identifies the factors of the development of the open innovation model in the modern world. As a result of the study, the authors have identified the factors that determine the transition of companies to the open innovation model from the traditional closed innovation model.
\end{abstract}

Keywords: Open Innovation; Closed Innovation; Innovation Process; Fostering Innovation.

\section{RESUMEN}

Las empresas transnacionales modernas están recurriendo cada vez más al modelo de innovación abierta. El papel de la innovación está creciendo en todo el mundo. El desarrollo e implementación de innovaciones en las actividades actuales de las empresas caracterizan el desarrollo competitivo efectivo de una organización en el mercado. Este modelo tiene una serie de ventajas: un desarrollo más rápido de las innovaciones, la capacidad de ahorrar en I + D a través de la externalización de innovaciones, el acceso a las innovaciones más modernas de otras empresas, etc. El propósito de este estudio es identificar los factores que determinan la transición de un número creciente de empresas en el mundo al modelo de innovación abierta. En este artículo, utilizando el análisis de la literatura académica, se han considerado diversas visiones sobre este proceso. El trabajo identifica los factores del desarrollo del modelo de innovación abierta en el mundo moderno. Como resultado del estudio, los autores han identificado los factores que determinan la transición de las empresas al modelo de innovación abierta desde el modelo tradicional de innovación cerrada.

Palabras clave: Innovación Abierta; Innovación cerrada; Proceso de innovación; Fomento de la innovación. 


\section{INTRODUCTION}

Today, the role of innovation is growing all over the world. The development and implementation of innovations in the current activities of companies characterize the effective competitive development of an organization in the market. However, practice shows that the usual method of R\&D management, which predominantly involves the use of the organization's own developments, in the modern world in many cases becomes ineffective: for example, the company's own developments are not always able to be implemented and be successful in the market due to the organization's limited resources, lack of knowledge in certain areas and underdevelopment in R\&D (Chesbrough, Bogers, 2014; Chesbrough, 2020; Salampasis, Mention, 2019). To improve the efficiency of innovation activities of organizations, the use of new ways and methods of innovation management is of decisive importance (Rajput, Singh, 2019; Koh et al., 2020). One of the most relevant and effective ways to manage innovation is the open innovation concept (Chesbrough and Crowther, 2006).

In 2003, Professor at the University of California (Berkeley) Henry Chesbrough concluded that it could not be that all the smartest and most talented people worked for one company, so one needed to be able to work with smart employees, both inside and outside the organization (Chesbrough, 2003). It was Chesbrough who gave impetus to the development of a new model of innovation management in companies - the open innovation model.

An organization, when developing new technologies and products, services, not only uses its own internal corporate R\&D but also actively outsources innovations and competencies (McGee et al., 1995; Pisano, 1990). Innovations and developments emerge in an organization not in "closed" specialized departments, but come from the external market (Kodama, 2005a; Kodama, 2005b; Hartmann, 2014). More than half of the innovations in a company are not own developments, but innovations acquired or borrowed from the external market and brought to the final product (West, Gallagher, 2006).

The open innovation model offers many benefits to organizations working in a global collaboration framework (Trapp, 2014; Lichtenthaler, Lichtenthaler, 2009):

- reducing the cost of R\&D;

- potential for improving development efficiency;

- connecting different clients at the beginning of the R\&D process;

- improving the accuracy of marketing research and focus on the buyer/client;

- potential for synergy between external and internal developments;

- potential for viral marketing.

The open innovation model poses many risks to companies (West, Gallagher, 2006):

- risk of disclosing and losing important personal information;

- risk of losing an advantage over competitors;

- increased complexity of control and management of innovations; 
- changing innovation strategies to go beyond the company in order to maximize the return on external innovation.

It should be noted that the closed innovation model has been successfully operating on the market for a long time and has shown good results. However, due to the development of the economy, the constantly changing market and other fundamental factors, the closed innovation model has ceased to justify itself, which gave impetus to the emergence of a new model - the open innovation (Trott, Hartmann, 2009).

The purpose of this study is to identify the factors that determine the transition of an increasing number of companies in the world to the open innovation model. In this study, using the analysis of academic literature, various views on this process have been considered.

\section{MATERIALS AND METHODS}

As part of this study, the authors conducted a retrospective analysis of the academic literature in order to identify the development factors of the open innovation model. To do this, the authors studied the literature on open innovation, new models of innovation, fostering innovations, etc. The authors looked for the opinions and conclusions by scholars regarding what, or which factors, in their opinion, stimulated the development of the open innovation model.

\section{RESULTS}

As a result of the study, the authors have identified the following factors that determine the transition of companies to the open innovation model from the traditional closed innovation model.

\subsection{Growth in venture capital.}

Over the past decades, there has been a significant leap in capital growth spent on the creation of companies that commercialize knowledge coming from external resources (Pradhan, 2018). It is these startups that have become serious competitors for large, industry-leading organizations. In addition, due to the emergence of the concept of open innovation, it was these large industry leaders who invested in the innovations and developments being the basis for creating products and services of startups (Pradhan, 2019).

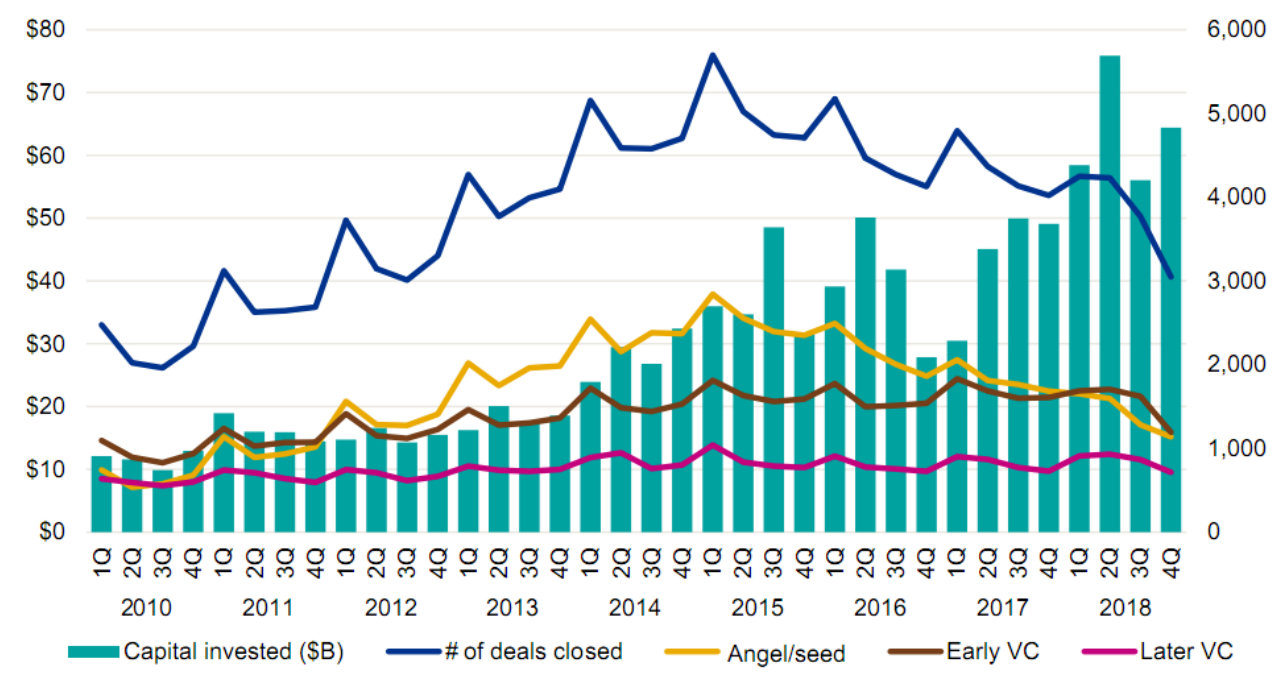

Source: Lavender et al., 2019

Figure 1. Global venture financing by stage 2010-Q4'18 
In the last quarter of 2018, venture capital investments worldwide totaled almost USD 64 billion, which ultimately led to an increase in venture capital investments in 2018 to USD 255 billion, up from just USD 175 billion in 2017.

The growth of venture capital increases the mobility of workers and the number of people with higher education. All this contributes to the fact that knowledge can be brought to the market in different ways (Figure 2).

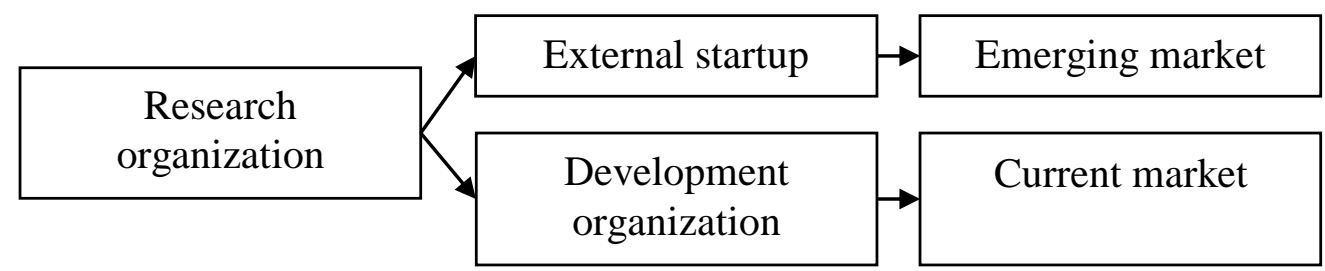

Source: Chesbrough et al, 2006

Figure 2. Opportunities for implementing knowledge within the framework of the open innovation model

According to the closed innovation model, the developers had to wait until a certain number of specialists began to introduce their created innovations to the external market. Now the ideas of developers can get implementation outside of an organization, in other words, move to a new organization for implementation in another market (Helfat, 2006).

\subsection{Increased competition}

Increased competition leads to the development of innovations and, therefore, the supply of new knowledge increases in the entire market. In other words, the number of organizations creating innovations is increasing, and all this leads to the need to increase funding for $R \& D$ to eliminate competitors (Lefouili, 2015). To become a market leader, companies begin to focus on a small number of innovative projects, as a result of which they begin to invest in a less wide range of developments, making the company invest in only special industries. As a result, all this increases the likelihood of the project being successful and, accordingly, faster delivery of the final result compared to those companies that have their own large research centers and distribute their investments across a variety of investment projects and developments (Calvano, Polo, 2020). However, as companies are not always able to be leaders in all industries and in order not to lose a competitive advantage in certain areas, companies are forced to attract external partners or buy innovations on the external market. All of the above stimulates the exchange of knowledge and technologies, thus creating the ground for the emergence of a new model of innovation development - the open innovation (Galvin, 2020).

\subsection{Increasing the role of universities as centers of innovation creation}

The decline in government funding for university research has created incentives for these universities to seek new sources of funding for their research and development among companies (Crespi et al., 2011). So, universities have become well versed in financing, finding investors, and other business issues. According to the data of Chesbrough et al. (2006), in 1980-1990, it became a generally accepted fact that the US universities and patent system are one of the most important sources of the US economic growth, determining its competitiveness in the world, explained by the increasing importance of R\&D for the US innovative development.

The knowledge that is now being created in universities has become more focused on specific goals that can be commercialized. Confirmation of all this is the increase in patents obtained by universities. 


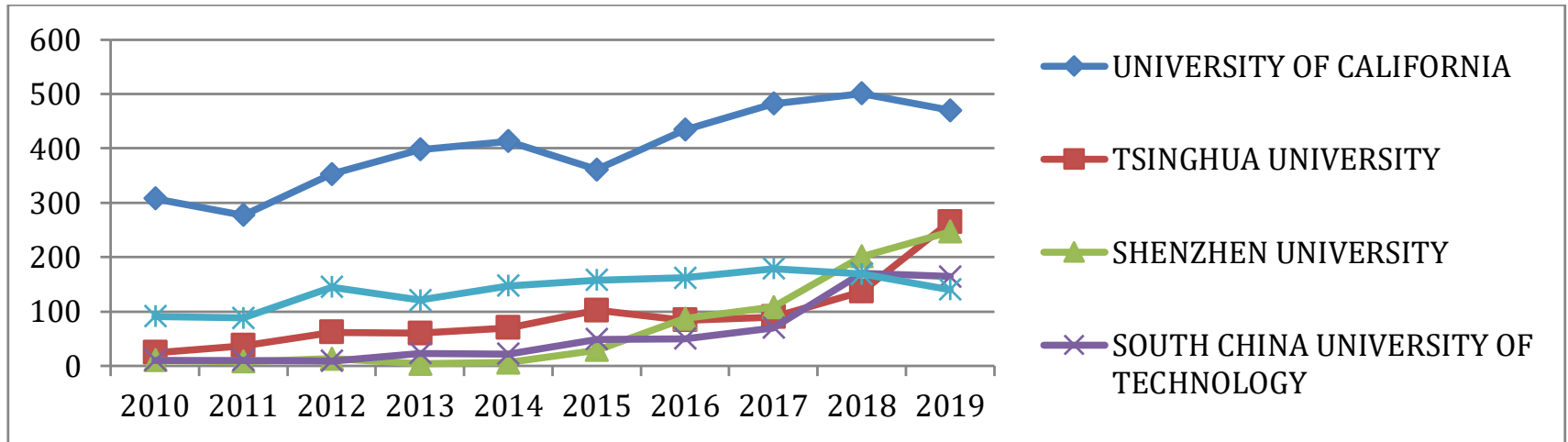

Source: WIPO Statistics Database, April 2020

Figure 3. Statistics of patents received by the largest universities in the world

Universities are characterized as "an engine for economic growth" and legalization and commercialization of their research results is the only way to preserve, attract, and reward gifted scientists who strive to see that their research results are used for the benefit of society (Thursby, 2009).

\subsection{Increasing circulation of knowledge}

At the time when the "closed innovation" model was successfully operating in the market, some large research centers were monopolies in the ownership of knowledge (Huizingh, 2011). With the spread of knowledge, this monopoly began to weaken, which subsequently led to the emergence of the open innovation model. It is worth noting that this fact was the cornerstone in the transition from the old model of closed innovation to the new one.

Thus, all of the above factors contributed to global changes: the destruction of the old model of "closed innovation" and added new points to the cycle of creating innovations (Figure 4).

Figure 4 shows a startup in its development. This possibility is not inherent in the closed innovation model, as funds spent on innovation and development may not generate income. Therefore, the closed innovation model cannot exist due to the erosion of the title to the results of scientific activity. See the figure below for details.

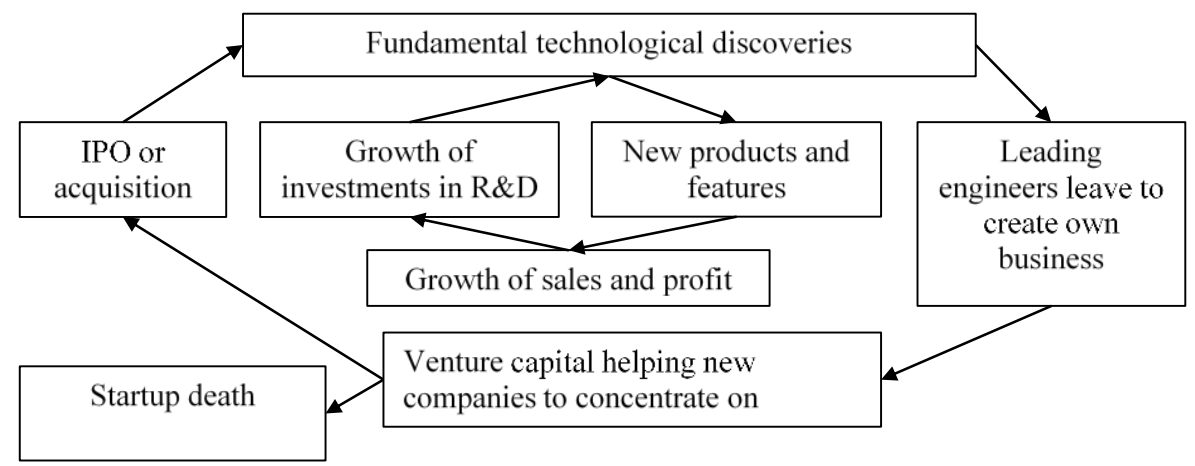

Source: Chesbrough, 2003

Figure 4. The process of creating innovations in the framework of the functioning of the open innovation model 
A comparison of the basic principles of the models of closed and open innovations (Table 1) describes the main criteria of the traditional approach in the management of innovation and the use of a new format (Chesbrough, Bogers, 2014; Chesbrough et al., 2006; Chesbrough, 2003; Dahlander, Gann, 2007).

Table 1. Contrasting principles of closed and open innovation

\begin{tabular}{|l|l|}
\hline Principles of closed innovation & Principles of open innovation \\
\hline $\begin{array}{l}\text { The smart people in this field work for one } \\
\text { company. }\end{array}$ & $\begin{array}{l}\text { Not all the smart people work for one company. It } \\
\text { must find and tap into the knowledge and expertise of } \\
\text { individuals outside the company }\end{array}$ \\
\hline $\begin{array}{l}\text { To profit from R\&D, the company should } \\
\text { develop and deliver innovation to the end-user } \\
\text { itself. }\end{array}$ & $\begin{array}{l}\text { The finished product comprises external and internal } \\
\text { cooperation chains. }\end{array}$ \\
\hline $\begin{array}{l}\text { The company which is the first to develop the } \\
\text { innovation will win the market. }\end{array}$ & $\begin{array}{l}\text { The company does not have to originate the } \\
\text { innovation to profit from it. }\end{array}$ \\
\hline $\begin{array}{l}\text { The company which is the first to commercialize } \\
\text { the innovation in the market will win. }\end{array}$ & $\begin{array}{l}\text { The company with a better and higher quality product } \\
\text { will win. Bringing the innovation first to the market is } \\
\text { not better. }\end{array}$ \\
\hline $\begin{array}{l}\text { The company which creates the most and best } \\
\text { innovations in the industry will win. }\end{array}$ & $\begin{array}{l}\text { The company which will make the best use of } \\
\text { external and internal ideas will win. }\end{array}$ \\
\hline $\begin{array}{l}\text { The company should control intellectual property } \\
\text { so that competitors would not profit from it. }\end{array}$ & $\begin{array}{l}\text { The company should profit from using others' ideas } \\
\text { and sell own ideas to external players. }\end{array}$ \\
\hline
\end{tabular}

The open innovation model implies the use of specialized knowledge flows to increase internal innovation processes and to expand markets for better use of innovation. The open innovation model contains a process where research and development are in the public domain. An organization can use not only its internal innovations when entering the market but also innovations and developments acquired in cooperation with external companies. According to the theory of open innovation, all knowledge is widely circulating, and therefore companies get the maximum effect when they acquire (buy or license) the results of inventions of other companies and share (open for license and sell) their innovations.

Invention is not innovation. Innovation is, first and foremost, meeting customer needs in a new way. Therefore, invention is part of innovation. A person can be an inventor, but not an innovator. Only an innovator, a person who has invented a new way to meet customer needs, has the greatest profit in the market. The open innovation model allows ideas, inventions, and technologies to be used only in places where they are truly valued.

There are the following disadvantages of a closed innovation generation process in companies:

- a company operating under the closed innovation model spends enormous resources, but it could solve current issues in the external market, where everything is available at relatively low prices;

- most of what a company has developed is not used by it, and, accordingly, does not bring profit;

- often companies "sweep aside" many projects that are really valuable to them, are simply not applicable within the organization, or do not correspond to business models.

The use of the open innovation model in comparison with the logic of the closed innovation model requires a special attitude toward the situation. In addition, the open innovation model requires special skills and focus of attention, namely: 
- in order to create an innovative product, it is necessary to analyze the entire value chain in the industry (from suppliers to end-users), since an innovative product is a one that contains all the key unresolved needs of customers;

- the main work in the open innovation model is, first of all, the search for ideas, solutions, and technologies that will be used to create the final product and meet the needs of customers. The foreign market contains many different inventions and technologies, so there is nothing to invent. One can use, buy, and license technologies and apply them for own purposes and in various fields;

- the open innovation model requires innovators to be communicative and, accordingly, to have mutually beneficial cooperation with a large number of a wide variety of companies and people. The choice of the most reliable partners/suppliers who will not fail and will be able to evaluate the idea, develop it, and bring it to the final product is of great importance.

\section{DISCUSSION}

The main objectives of the open innovation model are the effective use of innovation, motivation, and integration (West, Gallagher, 2006), and its main strategies are:

1. Combining the development and research process into a common fund.

2. Separate parts of an innovative product are developed by separate organizations.

3. Developments of extensive application are freely available for use and creation of various innovative products.

4. Bureaucracy in large companies is significantly reduced in the field of innovation due to various open innovation processes.

The effective functioning of the open innovation model for joint development and research requires the creation of various partnerships (Chesbrough, Schwartz, 2007). These partnerships will create an optimal business model, reduce R\&D costs, increase production, and create completely new markets for innovative products. However, for this, organizations first need to identify the main goals for the business process as a whole and also the business goals for the individual partner; classify the company's R\&D capabilities; coordinate all business models for companies participating in the innovation process.

According to the theory of the open innovation model, it carries the meaning of destruction and not using internal laboratories of the organization, but implies a symbiosis of using internal and external sources of knowledge. In other words, the organization should not focus on itself in R\&D and thus miss out on innovations generated outside the company. Using the open innovation model, the organization should use knowledge and experience in the external market in research. Now the research team has new responsibilities and authorities: in addition to carrying out own developments and research, research activities now mean the analysis, assessment, and integration of external knowledge. Also, internal research teams of the company should deal with the creation of missing knowledge in certain industries that does not exist either inside or outside the company; in addition, the company should also be engaged in assessing the possibility of earning income from the knowledge that the organization has, using external sources of knowledge (Dahlander, Gann, 2007).

It should be noted that the protection of intellectual property rights of a company is also an important point in the conditions of the open innovation model, as well as in the conditions of the closed innovation model. At the same time, companies using the open innovation model have a different attitude toward the 
protection of intellectual property rights. Such companies understand that it will be impossible to hide successful know-how in the market from competitors, since a new technology, service, or product that is in great demand will inevitably be copied and distributed in the current environment (Huston, Sakkab, 2007). Moreover, a patent is obtained for a method of obtaining it, and not for a result, but the developers who have come up with a new way of obtaining such a result can change this method in such a way that it does not fall under a patent, or create a new method. Therefore, organizations operating under the open innovation model often use licensing in order to create and expand markets for their developments. Therefore, both players win: the company that creates know-how receives a stable profit, and the competitors, accordingly, do not need to bear additional costs for their own development of some new product (Lichtenthaler, 2007). According to this approach, internal competition is created within the company, which motivates internal divisions. Companies adopting the open innovation model keep this kind of competition alive in small volume: internal $R \& D$ teams will be faster and more efficient in order to provide the marketing department with a new development at the right time; otherwise they will receive the necessary development outside the company, and marketing departments, in turn, will work more on a new product if there is a risk of outsourcing development. Therefore, the company always wins, since the company will have protection against late entry into the external market (Helfat, Quinn, 2006).

\section{CONCLUSIONS}

Already since its emergence, the open innovation model has become attractive to small companies, while the question arose at that time whether the giant companies would be able to use this model, because they own large research centers, huge personnel potential, and large financial resources. The main and first example in the history of using the "open innovation" model by large companies is the case of the International Business Machines Corporation (IBM), which proved that large companies can integrate their own and others' innovations.

\section{REFERENCES}

Calvano, E., Polo, M. (2020). Market power, competition and innovation in digital markets: A survey. Information Economics and Policy, 100853. https://doi.org/10.1016/j.infoecopol.2020.100853

Chesbrough, H. (2020). To recover faster from Covid-19, open up: managerial implications from an open innovation perspective. Industrial Marketing Management, 88, 410-413. https://doi.org/10.1016/j.indmarman.2020.04.010

Chesbrough, H., Bogers, M. (2014). Explicating open innovation: clarifying an emerging paradigm for understanding innovation. New Frontiers in Open Innovation. Oxford: Oxford University Press.

Chesbrough, H., Crowther, A.K. (2006). Beyond high tech: early adopters of open innovation in other industries. R\&D Management, 36(3), 229-236.

Chesbrough, H., Schwartz, K. (2007). Innovating business models with co-development partnerships. Research-Technology Management, 50(1), 55-9.

Chesbrough, H.W, Vanhaverbeke, W., West, J. (2006). Open innovation: Researching a new paradigm. Oxford: Oxford University Press.

Chesbrough, H.W. (2003). The open-innovation model. MIT Sloan Management Review, 44(3), 35-41.

Crespi, G., D'Este, P., Fontana, R., Geuna, A. (2011). The impact of academic patenting on university research and its transfer. Research Policy, 40(1), 55-68. https://doi.org/10.1016/j.respol.2010.09.010 
Dahlander, L., Gann, D. (2007). How Open is Innovation? Copenhagen: DRUID.

Galvin, P., Burton, N., Singh, P.J., Sarpong, D., Bach, N., Teo, S. (2020). Network rivalry, Competition and Innovation. Technological Forecasting and Social Change, 161, 120253. https://doi.org/10.1016/j.techfore.2020.120253

Hartmann, P.M., Zaki, M., Feldmann, N., Neely, A. (2014). Big data for big business? A taxonomy of data-driven business models used by start-up firms. Cambridge: Cambridge Service Alliance.

Helfat, C.E. (2006). Open innovation: the new imperative for creating and profiting from technology. Academy of Management Perspectives, 20(2), 86-88. https://doi.org/10.5465/amp.2006.20591014

Huizingh, E.K.R.E. (2011). Open innovation: state of the art and future perspectives. Technovation, 31(1), 2-9.

Huston, L., Sakkab, N. (2007). Implementing open innovation. Research Technology Management, 50(2), $21-25$.

Kodama, M. (2005a). Knowledge creation through networked strategic communities: case studies on new product development in Japanese companies. Long Range Plann, 38(1), 27-49.

Kodama, M. (2005b). How two Japanese High-Tech Companies Achieved Rapid Innovation via Strategic Community Networks. Strategy \& Leadership.

Koh, L., Dolgui, A., Sarkis, J. (2020). Blockchain in transport and logistics-paradigms and transitions. International Journal of Production Research, 58(7), 2054-2062. https://doi.org/10.1080/00207543.2020.1736428

Lavender, J., Hughes, B., Speier, A. (2019). Venture Pulse: Q4'18 Global analysis of venture funding. KPMG International Cooperative ("KPMG International"). Retrieved from: https://assets.kpmg/content/dam/kpmg/xx/pdf/2019/01/kpmg-venture-pulse-q4-2018.pdf

Lefouili, Y. (2015). Does competition spur innovation? The case of yardstick competition. Economics Letters, 137, 135-139. https://doi.org/10.1016/j.econlet.2015.10.033

Lichtenthaler, U. (2007). The drivers of technology licensing: an industry comparison. California Management Review, 49(4), 67-89.

Lichtenthaler, U., Lichtenthaler, E. (2009). A capability-based framework for open innovation: complementing absorptive capacity. Journal of Management Studies, 46(8), 1315-1338.

McGee, J.E., Dowling, M.J., Megginson, W.L. (1995). Cooperative strategy and new venture performance: the role of business strategy and management experience. Strategic Management Journal, 16(7), 565-580.

Pisano, G.P. (1990). The R\&D boundaries of the firm: an empirical analysis. Administrative Science Quarterly, 35(1), 153-176.

Pradhan, R.P., Arvin, M.B., Nair, M., Bennett, S.E., Bahmani, S. (2019). Short-term and long-term dynamics of venture capital and economic growth in a digital economy: A study of European countries. 
Technology in Society, 57, 125-134. https://doi.org/10.1016/j.techsoc.2018.11.002

Pradhan, R.P., Arvin, M.B., Nair, M., Bennett, S.E., Bahmani, S., Hall, J.H. (2018). Endogenous dynamics between innovation, financial markets, venture capital and economic growth: Evidence from Europe. Journal of Multinational Financial Management, 45, 15-34. https://doi.org/10.1016/j.mulfin.2018.01.002

Rajput, S., Singh, S.P. (2019). Connecting circular economy and industry 4.0. International Journal of Information Management, 49, 98-113.

Salampasis, D., Mention, A.L. (2019). From a-value to value-multiplication: leveraging outbound open innovation practices for unrelated diversification in the sensorindustry. Technology Analysis and Strategic Management, 31(11), 1327-1340.

Thursby, J., Fuller, A.W., Thursby, M. (2009). US faculty patenting: Inside and outside the university. Research Policy, 38(1), 14-25. https://doi.org/10.1016/j.respol.2008.09.004

Trapp, M. (2014). Realizing Business Model Innovation: A Strategic Approach for Business Unit Managers. Springer Science \& Business Media.

Trott, P., Hartmann, D.A.P. (2009). Why 'open innovation' is old wine in new bottles. International Journal of Innovation Management, 13(04), 715-736.

West, J., Gallagher, S. (2006). Challenges of open innovation: the paradox of firm investment in opensource software. R\&D Management, 36(3), 319-331. https://doi.org/10.1111/j.1467-9310.2006.00436.x

WIPO Statistics Database. (April, 2020). Top PCT Applicants. Retrieved from: https://www.wipo.int/ipstats/en/statistics/pct/xls/y top applicants.xlsx 